\title{
Education is an Innovative Development of Internet Thinking and Ideological Politics
}

\author{
SHE San-chi \\ Institute of Marxism \\ Wuhan polytechnic \\ Wuhan 430074, China \\ 385916301@qq.com
}

\begin{abstract}
With the rapid development of information technology, the Internet has influenced and intervened in a series of major changes in global social economy since the 20th century, changing people's traditional production and life style. College students are the main force of network society, and college campuses are the area with high Internet penetration rate. The Internet has become a new environment for the growth and development of students, talent cultivation and education in colleges and universities. People use Internet thinking to promote the innovative development of ideological and political education, realize the high integration of traditional advantages and information technology of ideological and political education, and enhance its sense of times and attraction, which is an urgent subject that the current society must face and solve.
\end{abstract}

Keywords-Internet thinking; Ideological politics; Innovation and development

\section{INTRODUCTION}

The development of education teaching is deeply influenced by social development. Whether new social concepts emerge or new social and technological development, education teaching will have an impact on the development of education teaching, which also highlights the continuous development of education. Ideological and political education is widely carried out in China's higher education, and its significance and importance are self-evident. In the Internet era, thinking about the development and development of ideological and political education is a reflection of education's advancing with The Times. Secondly, under the new education concept, it is very important to introduce all elements conducive to teaching development into teaching. Therefore, it is of far-reaching significance to introduce the advanced technology elements in the Internet era into education. The current higher vocational college innovation 'thought politics lesson"practice teaching thought.

\section{THE DIVERSITY OF EDUCATION IN IDEOLOGICAL POLITICS IN THE INTERNET ERA}

Under the background of the Internet era represented by information technology, the development of university students' ideological and political education is a very important aspect, which lies in the extensive application of technical teaching resources. First of all, in the era of mutual display network, multimedia technology develops rapidly. Video, animation, image and other multimedia teaching resources are widely used in education, which is of great significance to the development of curriculum. For example, when education is carried out in ideological and political affairs, some teaching contents can be explained, and a video or micro-animation can be carried out, which not only enhances students' interest in learning, but also effectively carries out teaching. Secondly, in the context of the Internet era, there are also a large number of technical teaching resources at the information level. The introduction of new media teaching resources in education is also crucial. For example, based on ideological and political education courses, a public account of Webchat can be established, or students can follow it on microblogs. Teachers can regularly push relevant teaching content and materials to realize comprehensive teaching for students. In general, under the background of the Internet era, technical resources conducive to the development of teaching will be constantly introduced into teaching, which will not only promote the improvement of teaching quality level, but also have positive significance for curriculum reform.

\section{IN THE INTERNET ERA, ONLINE IDEOLOGICAL AND POLITICAL EDUCATION HAS BEEN WIDELY CARRIED OUT}

Online learning mode of conducting ideological and political education is a very broad concept, not only reflected in the course of classroom education, especially under the background of the Internet age, the course teaching greatly expand the range of using the technology platform to carry out the teaching, also is under the background of the Internet era, the ideological and political education to carry out the important direction, namely online learning mode carried out a lot. First of all, the Internet platform is used to build a corresponding learning system. In the online learning system, students begin to learn. For example, a large amount of teaching content of situation and policy courses is put on the Internet, and students can study according to the requirements in the online platform. They can watch video or read articles. Secondly, the development of online learning mode is a very important advantage, that is, students can flexibly arrange their own time to conduct online learning. In addition, in the online learning platform, there are abundant learning resources and students can conduct selective learning, which is also powerful for the development of students' learning interests. It is worth mentioning that the online learning model is widely developed and must be adjusted when it is applied in ideological and 
political teaching. For example, in the online learning platform, the selection of teaching resources, the division of teaching modules, etc. .

\section{USE THE NETWORK TO CARRY ON THE IDEOLOGICAL AND POLITICAL TEACHING FEEDBACK TO IMPLEMENT THE COMMUNICATION BETWEEN TEACHERS AND STUDENTS}

In the context of the Internet era, education teaching of college students' ideological and political science has an important direction to develop, which can systematize, make platform and make teaching feedback efficient. Teaching feedback is simply students' feedback on teaching development. For example, students' opinions and Suggestions on teaching methods, teaching modes and other aspects of teaching development, students' thinking on education and even students' problems in teaching contents are all important components of teaching feedback. The ultimate purpose of teaching feedback is to achieve communication between teachers and students. However, under the traditional mode of ideological and political teaching, it is unrealistic to conduct extensive communication. In the context of positive introduction of systematic teaching feedback, in education of ideological and political science, students and teachers conduct extensive exchanges, so as to timely solve the existing problems in teaching and deepen the understanding of teaching between teachers and students, which is very beneficial to the development of education of ideological and political science. It is worth noting that after the establishment of such an exchange platform, it is necessary to strengthen the supervision of the platform's speech and maintain a good teaching exchange and communication environment.

\section{MOOCS, COMMUNITIES PLATFORM AND BBS PROVIDE STUDENTS WITH A VARIETY OF LEARNING OPTIONS}

It emphasizes subjectivity and independence. The core idea of Internet thinking is that the Internet always follows user thinking in its development, highlighting user supremacy, people-oriented and experience as the king. Internet enterprises are constantly pursuing focus, perfection, word-of-mouth and speed, so that students who grow up in the Internet environment will pay more attention to the sense of experience, sense of achievement and satisfaction. The learning platform provided by the Internet gives students a variety of choices. Online interactive question-and-answer platform and community, "Moocs" and other platforms provide more auxiliary channels outside the classroom for students' learning, and students take the initiative to find the information they need in the online world. In the process of knowledge inquiry, they are more willing to participate in the r\&d and design process, express themselves and show their independence and uniqueness. In social practice, "I want to do it" is more reflected than "I want to do it", and more attention should be paid to the process of doing it to meet my own feelings and satisfy my own personality and needs. Therefore, we need to provide a more active platform to reflect students' subjectivity, and guide students to gain growth and reflect value in actively participating in the learning activities that are beneficial to the body and mind.
The innovative development of the Internet has expanded the thinking horizon and research methods of the subject of education in ideological and political affairs. First of all, Internet platforms and big data applications keep enriching and broadening the thinking horizon of education subjects in ideological and political affairs. In the practice of education in ideological and political affairs, there exists a process of continuous understanding and deepening understanding between educators and educatees, educators and education contents. In the early practice of ideological and political education, due to the limitation of subjective cognition and objective tools of education and other factors, it is easy for educators to have one-sided understanding and grasp of education objects and education contents. In the Internet era, abundant information resources and convenient communication methods have gradually broadened the thinking horizon of education subjects and deepened and comprehensive understanding of education objects and education contents, which has also improved the practical ability of education subjects in ideological and political affairs. Secondly, the research methods of education subject of ideological and political science are more diversified and convenient. Education is a science, which has strong practicality on the one hand and rich theoretical implication on the other. Ideological and political education workers need to face the objective development reality, adhere to the problem orientation, and keep innovating the basic theories, so as to meet the practical needs of the practical development of ideological and political education. In theoretical research, the innovation and development of the Internet has brought great convenience for the rich and innovative research methodology, the ideological and political education workers can through the Internet platform, using big data thinking, more quickly and effectively grasp the ideological and political education practice of objective reality, the creation and development of ideological and political education practice model, which makes the study of modern ideological and political education workers horizon and study efficiency and ability are improved. Thirdly, the work experience of education subject of ideological and political science is richer and fuller. In the Internet environment, the exchange of education subject and object of education is to improve, through effective online interactive, easy to get more information on the interaction of the educators and education feedback, which will enhance the ideological and political education the main body of the acquisition, satisfaction, on the other hand also will continue to improve the problems of ideological and political education main body consciousness and reality orientation, so as to enrich the ideological and political education main body of work experience.

The innovative development of the Internet has made education more flexible and diversified. The education mode of ideological and political affairs is directly related to the final effect of education practice. The education mode of diverse, flexible, continuous and vigorous promotion is more popular among contemporary youth. The innovative development of Internet provides necessary guarantee for the innovative development of education mode of ideological and political affairs. On the one hand, ideological and political education is much more diverse. The innovative development of the 
Internet has provided solid technical support for enriching the education mode of ideological and political affairs. It not only renews the cognition of the main body of education on education mode, but also continuously enriches and deepens the new education mode. "Moocs", "flipped classroom", "smart classroom" and various Internet communication platforms are playing an increasingly important role in education in ideology and politics with their unique ways and charm. On the other hand, the way ideological politics education is more metaphorical. Network is an important type of contemporary culture, network behavior has gradually become an important way of life, with his way of life, education for their popular phenomenon on the Internet culture education, highlights the concealment of the network ideological and political education, can make the education object in imperceptible to accept education

\section{SUMMARY}

This paper explores the ideological and political education of college students in the Internet era, and analyzes the development direction of ideological and political education of college students in combination with the characteristics of the
Internet era. In general, in the context of the Internet era, there will be many changes in the development of university students' ideological and political education. Continuous analysis of directional problems is of great significance to the implementation of teaching practice and should be attached great importance to. In addition, it is also the key to the development of education in ideology and politics to innovate thinking and introduce newideas in education teaching.

\section{REFERENCES}

[1] LAN Jiang. Research on the socialization of education in ideological politics [M].Hubei people's publishing house.2005:6.

[2] SUN Shu-wen. University ideological and political education socialization [J]. Value and path. Thought education research. 2011(2): 15.

[3] DAI Chun-ping. A new probe into the concept of education socialization in college students' ideological politics[J].Journal of Wuhan university of science and technology.2008(1):83.

[4] ZHANG Wei-ping. On modernization of ideological and political work [J].Journal of Xi 'an University of Political Science.2000 (1):7. 